Intersections

Canadian Journal of Music

Revue canadienne de musique
Intersections

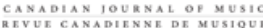

\title{
In and Out of the Sound Studio: a Resource List
}

\section{Lisa Gasior}

Volume 26, numéro 2, 2006

In and Out of the Sound Studio

URI : https://id.erudit.org/iderudit/1013230ar

DOI : https://doi.org/10.7202/1013230ar

Aller au sommaire du numéro

Éditeur(s)

Canadian University Music Society / Société de musique des universités

canadiennes

ISSN

1911-0146 (imprimé)

1918-512X (numérique)

Découvrir la revue

Citer ce document

Gasior, L. (2006). In and Out of the Sound Studio: a Resource List. Intersections, 26(2), 118-124. https://doi.org/10.7202/1013230ar

Copyright ( C Canadian University Music Society / Société de musique des universités canadiennes, 2007
Ce document est protégé par la loi sur le droit d'auteur. L'utilisation des services d'Érudit (y compris la reproduction) est assujettie à sa politique d'utilisation que vous pouvez consulter en ligne.

https://apropos.erudit.org/fr/usagers/politique-dutilisation/ 


\title{
In ANd OUt of the Sound Studio: a Resource List
}

\author{
compiled by Lisa Gasior
}

\section{Texts: Books, ARTiCles AND Journals}

Aoyagi, H. 2005. Islands of eight million smiles: idol performance and symbolic production in contemporary Japan. Cambridge: Harvard University Asia Center, distributed by Harvard University Press.

Beebe, R., D. Fulbrook and B. Saunders, eds. 2002. Rock over the edge: transformations in popular music culture. Durham: Duke University Press.

Bernstein, J. ed. 2004. Women's voices across musical worlds. Boston: Northeastern University Press.

Bosma, H. 1998a. "Who Makes Electronic Music?" Switch: January 1998, Issue 4: <http://switch.sjsu.edu/nextswitch/switch_engine/front/front. php?artc $=155>$.

_. 1998b. "Gender and Electroacoustics." eContact! 1.1: 9 (3): <http://cec. concordia.ca/econtact/Women in ea/Bosma.html>.

- 2003. "Bodies of evidence, singing cyborgs and other gender issues in electrovocal music." Organised Sound: An international journal of music technology (Gender in Music Technology): Vol. 8 (1): 5.

Boyko, D. 1998. "Woman and House: an interview with Susan Frykberg." Musicworks Magazine: Fall 1998 (48): 40.

Brooks, I. 2000. "Asian Women in Music Today." Musicworks Magazine: Spring 2000 (76): 51.

Burns, L. and M. Lafrance. 2002. Disruptive divas: feminism, identity \& popular music. New York: Routledge.

Canty-Quinlan, S. and F. Areana, eds. 2002. Lusosex: gender and sexuality in the Portuguese-speaking world. Minneapolis: University of Minnesota Press.

Cook, S. and A. McCartney. 2001. "Gender and Sexuality." The Garland Encyclopedia of World Music, Volume 3: The United States and Canada. Edited by Ellen Koskoff, 87-102. New York: Garland.

Diamond, B. and P. Moisala, eds. 2000. Music and gender. Urbana: University of Illinois Press.

Dickson, K., ed. 2003. Movie music, the film reader. New York: Routledge.

Duke, D.G. 1998. "Notes Towards a Portrait of Barbara Pentland: Issues of Gender, Class, and Colonialism in Canadian Music." Musicworks Magazine: Summer 1998 (70): 16.

Ericson, M.D. 1996. Women and music: a selective annotated bibliography on women and gender issues in music, 1987-1992. New York: G.K. Hall. 
Essl, G. 2003. "On gender in new music interface technology." Organised Sound: An international journal of music technology (Gender in Music Technology): Vol. 8 (1):19.

Fenner, V. 2005. "Chantal Dumas: a passion for listening and for audio art." Musicworks Magazine: Spring 2005 (91): 14-21.

Fraser, N. "Women Composers, Spirituality and Healing." Musicworks Magazine: Spring 1985 (31): 19.

Friz, A. "The Loudspeaker as Instrument: the soundworks of Nancy Tobin." Musicworks Magazine: Spring 2004 (88): 40-51.

_.. "Heard but Unscene: Women in electronic music," <http://www.cutup.com/news/issuedetail.php?sid=334\&issue=3>

Frykberg, S. 1984. "Machinewoman." Musicworks Magazine: Summer 1984 (28): 14 .

Gasior, L. and A. McCartney. 2004. "Diane Lebœuf: from mixing boards to museums." Musicworks Magazine: Fall 2004 (90) 44-51.

_.2004. "In and Out of the Studio." Musicworks Magazine: Fall 2004 (90): 7-9.

Gasior, L. 2005. "That's Ms. Shelley Craig-re-recording mixer extraordinaire." Musicworks Magazine: Fall 2005 (93): 32-39.

Halstead, J. 1997. The Woman Composer: Creativity and the Gendered Politics of Musical Composition. London: Ashgate.

Hinkle-Turner, E. 2003. "Women and music technology: Pioneers, precedents and issues in the United States." Organised Sound: An international journal of music technology (Gender in Music Technology) : Vol. 8 (1): 31.

.2006. Women Composers and Music Technology in the United States. Burlington, Vermont: Ashgate Publishing Company.

Hutton, J. 2003. "Daphne Oram: Innovator, writer and composer." Organised Sound: An international journal of music technology (Gender in Music Technology): Vol. 8 (1):49.

Hymer, J. 2002. "From burning pianos to sound-mapping the Danube: the sound world of Annea Lockwood." Musicworks Magazine: Fall 2002 (84): 30-35.

Jarviluoma, H. 2000. "Local Constructions of Gender in a Finnish Pelimanni Musicians Group" in Music and gender, eds. B. Diamond and P. Moisala, 51-79. Urbana: University of Illinois Press.

Kennedy, K. 2000. "A few facets of Pamela Z." Musicworks Magazine: Spring 2000 (76): 5-10.

Magrini, T., ed. 2003. Music and gender: perspectives from the Mediterranean. Chicago: University of Chicago Press.

Malott, C. 2004. Punk rockers' revolution: a pedagogy of race, class, and gender. New York: Peter Lang.

McCartney, A. 1995a. "Inventing Images: Constructing and Contesting Gender in Thinking About Electroacoustic Music." Leonardo Music Journal: 5 (1995): 57-66.

- 1995b. "Whose Playground, Which Games and What Rules? Women Composers in the Digital Playground." Proceedings of the International Computer Music Conference: Digital Playgrounds, Banff, Alberta: 563-570. 
1997. "Review of Canadian Women Making Music (Kivi)." Canadian Journal for Traditional Music/Revue de musique folklorique canadienne: 25 (1997): 52.

. 1998. "Outside in the Machine: Women Composers of Electroacoustic Music in Canada" in Ghosts in the Machine: Women and Cultural Policy in Canada and Australia, eds. A. Beale and A.Van Den Bosch, 181-210. Toronto: Garamond.

- 2000. "Come Out and Play! Why are Gender and Feminist Studies So Late to Come to Music?" Ctrl+Shift Art Ctrl+Shift Gender: Convergences of Gender, New Media and Art. Amsterdam: Axis Voor de Kunsten V/M: $18-21$.

. 2000. "Hildegard Westerkamp's Moments of Laughter: Recording childhood, performing motherhood, refusing to shut up, and laughing." Perspectives of New Music: 38 (1): 101-128.

-2002. "New Games in the Digital Playground: Women Composers Learning and Teaching Electroacoustic Music." Feminism \& Psychology SAGE: 12 (2): 160-167.

McCartney, A. and E. Waterman, eds. 2007. "In and Out of the Sound Studio: Women, Gender and Technology." Special issue of Intersections (formerly Canadian University Music Review). (Forthcoming as Issue 26/2, 2007).

Mountain, R. 2003. "The Expansive Spirit of Marcelle Deschênes." Musicworks Magazine: Summer 2003 (86): 14.

Nehring, N. 1997. Popular music, gender, and postmodernism: anger is an energy. Thousand Oaks: Sage Publications.

Norman, K. 2004. Sounding Art: Eight Literary Excursions through Electronic Music. London: Ashgate.

Pegley, K. 2000. "Gender, Voice, and Place: Issues of Negotiation in a 'Technology in Music Program," in Music and gender, eds. B. Diamond and P. Moisala, 306-316. Urbana: University of Illinois Press.

Pough, G. 2004. Check it while I wreck it: Black womanhood, hip hop culture, and the public sphere. Boston: Northeastern University Press.

Reynolds, S. and J. Press. 1996. The sex revolts: gender, rebellion, and rock'n'roll. Cambridge: Harvard University Press.

Riley, T. 2004. Fever: how rock ' $n$ ' roll transformed gender in America. New York: St. Martin's Press.

Sandstrom, B. 2000. "Women Mix Engineers and the Power of Sound" in Music and gender, eds. B. Diamond and P. Moisala. Urbana: University of Illinois Press.

Schippers, M. 2002. Rockin' out of the box: gender maneuvering in alternative hard rock. New Brunswick: Rutgers University Press.

Smith, L. C. 2001. "Composing Identity: What is a Woman Composer?" Musicworks Magazine: Summer 2001 (80): 26.

Truax, B. 2003. "Homoeroticism and Electroacoustic Music: Absence and Personal Voice." Organised Sound: 8 (1): 117-124.

Waterman, E. 2002. "A Making No Noise: The Mannlicher Carcano Radio Hour" Musicworks Magazine: 2002 (84): 36-43. 
2006a. "Purposeful Play: Women Radiomakers in Community-Based Campus Radio in Canada." Atlantis: A Women's Studies Journal: 30.2 (2006): 76-87.

- 2006b. "Radio Bodies: Discourse, Performance, Resonance" in Radio Territories, eds. B. LaBelle and E. G. Jensen. Los Angeles: Errant Bodies Press, (forthcoming).

-2006c. "Revisiting Haraway's Cyborg: the Non-innocent Music of Ellen Waterman." Vague Terrain 04: The Body Digital. <http://www.vagueterrain. net>

Weaver, C.A. 1988. "Timbrel in Her Hand: Woman-Voice (with Judith Miller)." Musicworks Magazine: Fall 1988 (42): 24-27.

-1995. "Kenyan Women's Music as Agent of Social and Cultural Change." Musicworks Magazine: Spring 1995 (61): 8.

Weber-Lucks, T. 2003. "Electroacoustic voices in performance art: A gender issue?" Organised Sound: An international journal of music technology (Gender in Music Technology) : Vol. 8 (1):61.

Whiteley, S. 1997. Sexing the groove: popular music and gender. New York: Routledge.

Wolf, S. E. 2002. A problem like Maria: gender and sexuality in the American musical. Ann Arbor: University of Michigan Press.

Women and Music. Annual Journal. Lincoln, NE: University of Nebraska Press.

\section{Sound Works, Performances \& Presentations}

Babin, Magali. Chemin de fer. Montréal: No Type, 2002. Audio CD.

- Spick Up. Montréal: No Type Annexe, 2000. Audio CD.

Babin, Magalie and I8U. Peak. Montreal: Independent, 2003. Audio CD.

Barrett, Natasha. Chillies \& Shells. Independent, 1998. Audio CD.

—. Isostasie. Montréal: empreintes DIGITALes, 2002. Audio CD.

- Rocks \& Wraiths. Independent, 1997. Audio CD.

Bartley, Wende. Clair-voix. Montréal: empreintes DIGITALes, 1994. Audio CD.

Bergeron, Myléna. Chronopée (1). Montréal: Oral, 2002. Audio CD.

- Chronopée (2). Montréal: Oral, 2006. Audio CD.

Bokanowski, Michèle. Létoile absinthe. Cinéma pour l'oreille, 2002. Audio CD.

- Cirque. Montréal: empreintes DIGITALes, 1995. Audio CD.

Tabou. Cinéma pour loreille, 1994. Audio CD.

Bosma, H. "Écriture Féminine in electrovocal music." Feminist Theory and Music 4 Conference: University of Virginia, Charlottesville, VA, USA. 1997: $<$ http://www.hannahbosma.nl/paperFTM4.html>

Boudreau, Michelle. Ma Magie. Independent, 2003. Audio CD.

_. Des passages de Charnière + Ma magie et autres pièces. Independent, 2004. Audio CD.

Chuengsatiansup, Komatra. "Sense, Symbol, and Soma: Illness Experience in the Soundscape of Everyday Life." World Forum for Acoustic Ecology: Hirosaki University, Hirosaki, Japan. November 2, 2006. 
Coulombe Saint-Marcoux, Micheline. Impulsion. Montréal: empreintes DIGITALes, 2001. Audio CD.

Deschenes, Marcelle. petits Big Bangs. Montréal: empreintes DIGITALes, 2006. Audio CD.

Dumas, Chantal. "Le parfum des femmes." <http://www.transradio.org/fdle/ index_noflash.php>

_ . "Riding Along with Luc Ferrari." <http://www.kunstradio.at/2006A/28 05_06.html>

__ "road movie." <http://www.transradio.org/fdle/index_noflash.php>

Frykberg, Susan. Astonishing Sense of Being Taken Over by Something Far Greater Than Me. Earsay, 1998. Audio CD.

Gasior, Lisa and Andra McCartney. "Talk-Back Through Glass Windows and Ceilings." International Association for the Study of Popular Music: Carleton University, Ottawa, Canada. May 15, 2003.

Hartman, Hanna. Färjesånger, Cikoria, Die Schrauben.... Elektron, 2002. Audio $\mathrm{CD}$.

Hug, Charlotte and Chantal Laplante. Brilliant Days. For 4 Ears, 2003. Audio CD.

I8U. Obsacle. Montreal: Oral, 2002. Audio CD.

Jean, Monique. L’adieu au s.o.s. Montréal: empreintes DIGITALes, 2003. Audio $\mathrm{CD}$.

Labrosse, Diane. Face cachée des choses. Montréal, Ambiances Magnétiques, 1995. Audio CD.

Labrosse, Diane with Xavier Charles, Kristoff K.Roll and Martin Tétreault. Tout le monde en place pour un set américain. Montréal: Victo, 2003. Audio CD.

Labrosse, Diane with A_dontigny. Télépathie. Montréal: No Type, 2003. Audio $\mathrm{CD}$.

Labrosse, Diane with Martin Tétreault. Parasites. Montréal: Ambiances Magnétiques, 2001. Audio CD.

Labrosse, Diane with Iku Mori and Martin Tétreault. Île bizarre. Montréal, Ambiances Magnétiques, 1998. Audio CD.

Lesbians on Ecstasy. Lesbians on Ecstasy. Montreal: Alien 8, 2004. Audio CD.

Norman, Katherine. Sounding Art: Eight Literary Excursions through Electronic Music. Ashgate, 2004. Audio CD.

Peebles, Sarah. Insect Groove. Toronto: Cycling '74, 2002. Audio CD.

Poirier, Ghislain. Conflits. Montréal: Intr_version, 2003. Audio CD.

—. Sous le Manguier. Montréal: Intr_version, 2002. Audio CD.

Radigue, Éliane. Biogenesis. Montréal: Cinéma pour l'oreille, 1996. Audio CD.

Rousse, Julie. Rêve. PMS, 2004. Audio CD.

-Des restes humains. PMS, 2003. Audio CD.

Tobin, Nancy. Cruel Mystère. Montréal: Oral, 2002. Audio CD.

Truax, Barry. "Powers of Two." www.sfu.ca/ truax/cd7.html

. "Twin Souls." www.sfu.ca/ truax/cd6.html

Turcotte, Roxanne. Amore. Montréal: empreintes DIGITALes, 1994. Audio CD.

- Libellune. Montréal: empreintes DIGITALes, 2003. Audio CD. 
Vande Gorne, Annette. Tao. Montréal: empreintes DIGITALes, 1993. Audio CD.

- Le ginkgo; Architecture nuit; Noces noir. SONARt, 1995. Audio CD.

- Impalpables. Montréal: empreintes DIGITALes, 1998. Audio CD.

Waterman, E. 2006. "(Wo)Mannlicher Radio. Original work for electroacoustic soundscape and improvised flute." Included on CD for book Radio Territories, edited by B. LaBelle and E. G. Jensen. Los Angeles: Errant Bodies Press, (forthcoming).

Westerkamp, Hildegard. Transformations. Montreal: empreintes DIGITALes, 1996. Audio CD.

- Into India. Earsay, 2002. Audio CD.

\section{WEBSITES}

For a complete list of the participants of In and Out of the Sound Studio, with bios and links, please see In and Out of the Sound Studio, <http://www.andrasound. org >

Michele Anderson, <http://travelsandtunes.blogspot.com $>$

Hannah Bosma, <http://www.hannahbosma.nl>

Bosma, H. "Gender and Electronic Music." <http://www.hannahbosma.nl/ genelmus.htm>

Bosma, H. "Who creates electro-vocal music? (authors, composers, vocalists and gender)," <http://www.hannahbosma.nl/readaxHB.html>

Éveline Boudreau, <http://www.evelineboudreau.com>

Canadian Electroacoustic Community, <http://cec.concordia.ca $>$

Canadian Society for Independent Radio Production, $<\mathrm{http}: / / w w w . r a d i o s i t e . c a\rangle$

David Cecchetto, <http://www.conflations.com>

Owen Chapman, <http://www.opositive.ca $>$

Sylvie Chenard, <http://www.lesprojetsdelabaleine.net/>

CISM 89.3FM, <http://www.cismfm.qc.ca>

City in a Soundwalk, <http://www.cityinasoundwalk.org >

CKUT 90.3FM, <http://www.ckut.ca>

Critical Studies in Improvisation, <http://www.criticalimprov.com>

DJ Killa Jewel, <http://www.killajewel.com>

DJ Shortee, $<$ http://faustandshortee.com $>$

ElectroCD, <http://www.electrocd.ca $>$

Electronic Music Foundation, <http://www.emf.org >

Lisa Gasior, <http://www.griffinsound.ca>

Leela Gilday, <http://www.leelagilday.com $>$

I8U, <http://www.i8u.com>

In and Out of the Sound Studio, <http://www.andrasound.org $>$

INTD conference, <http://finearts.uvic.ca/collision $>$

Randolph Jordan, <http://www.soppybagrecords.net/randolph-jordan>

Journées sonores: Canal de Lachine, <http://artsandscience.concordia.ca/ facstaff/m-o/mccartney/lachine $>$

Kathy Kennedy, <http://www.kathykennedy.ca> 
Chantal Laplante, <http://www.chantalelaplante.com>

Andra McCartney, <http://www.andrasound.org>

New York Soundmap, <http://www.nysoundmap.org>

Québec Info Musique, <http://www.qim.com>

Rosenbrock, A., "I think I've never had a good idea inside the practice room,"

$<\mathrm{http}$ ://artsandscience.concordia.ca/facstaff/m-o/mccartney/inandout/ linked_items/rosenbrock.pdf>

Jacky Sawatzky, <http://www.jackysawatzky.net>

Sono-design, <http://www.sono-design.com>

Sounds Provocative: Experimental Music Performance in Canada, <http://www. experimentalperformance.ca>

Kinnie Starr, <http://www.kinniestarr.com>

Barry Truax, <http://www.sfu.ca/ truax $>$

Marian van der Zon, <http://www.fidgetsoundword.com>

Ellen Waterman, <http://www.uoguelph.ca/ ewaterma >

Ellen Waterman, <http://www.experimentalperformance.ca $>$

Hildegard Westerkamp, <http://www.sfu.ca/ westerka >

Andrea Young, <http://www.andreayoung.ca> 